\title{
TAJDÎD FIQH DARI KONSERVATIF TEKSTUAL MENUJU FIQH PROGRESIF KONTEKSTUAL
}

\author{
Nasrulloh \\ Fakultas Syariah UIN Maulana Malik Ibrahim Malang \\ nasrullah.said@gmail.com
}

\begin{abstract}
Abstrak
By reference to Rule (al-mashaqqah tajlib al-Taysir) and (idza dhaqa ittasa'a), the need to reconstruct the fiqh through tajdîd considered a necessity when there are difficulties to implement it. On one side there is an opinion that tajdîd should be limited to new problems that are not listed in the qath'i texts, but on the other hand argue that all texts are dzanni, so there is no limit in the realm of tajdid and ijtihad. Through this theme, the authors also cite some of the thinking that distinguishes between authenticity of the revelation as the God's will and the authenticity of Hadis which is still questionable. Then, a distinction efforts also should be made between the revelation of God's will as an ideal and the truth of human understanding (fiqh) that is relative so it needs to be reconstructed in order to remain relevant anywhere and anytime.
\end{abstract}

Dengan mengacu pada kaidah (al-mashaqqah tajlib al-taysîr) dan (idza dhâqa ittasa'a), kebutuhan untuk merekonstruksi fiqh melalui tajdîd dianggap sebuah keharusan manakala terdapat kesulitan untuk menerapkannya. Disatu sisi ada yang berpendapat bahwa tajdîd harus dibatasi pada masalah-masalah baru yang tidak tercantum dalam nash yang qath' $i$, namun pada sisi yang lain ada yang berpendapat bahwa semua nash bersifat dzanni, sehingga tidak ada batasan dalam ranah tajdîd dan ijtihad. Melalui tema ini, penulis juga mengutip beberapa pemikiran yang membedakan antara wahyu sebagai kehendak Tuhan yang otentik dan hadis yang masih perlu dipertanyakan keotentikannya. Disamping itu upaya pembedaan juga perlu dilakukan antara wahyu sebagai kehendak Tuhan yang ideal, dengan pemahaman manusia (figh) yang kebenarannya bersifat relatif sehingga perlu direkonstruksi agar tetap relevan dimanapun dan kapanpun.

Kata Kunci : Fiqh, Tajdîd, Ijtihad, Tekstual,

Ada kecendrungan fiqh sering disejajarkan dengan 'firman Tuhan', sehingga pendapat seorang faqîh disakralkan dan bahkan disetarakan dengan 'kalâm Tuhan'. Tidak sedikit dari para penggemar ilmu-ilmu agama Islam membuat pernyataan bahwasannya pintu ijtihad sudah tertutup, sehingga tidak mungkin ditemukan lagi seorang faqîh setingkat fuqaha' zaman klasik yang mampu memahami makna al-Qur'an dan al-Sunnah. Pernyataan semacam itu sepertinya masih mengakar kuat di benak para pengkaji ilmu-ilmu keislaman yang masih 'awam'. Paradigma semacam itu jika dibiarkan,

Prof Amin Abdullah, terbersit secara spontan dalam pikiran penulis untuk maka syariah Islam jelas tidak mungkin bisa relevan di manapun dan kapanpun, sehingga visi rahmatan lil 'alamîn tidak dapat terwujud. Karenanya agar syariah Islam yang dibawa oleh Nabi Muhammad Saw tetap relevan, maka perlu ada upaya obyektif kreatif inovatif,.

Setelah mengkaji dengan seksama pemikiran kreatif inovatif Khaled Abu el-Fadl dan Jaseer Audah, penulis menemukan banyak perubahan dalam memahami syariah Islam yang begitu fleksibel dan terbuka untuk interpretasi. Dari mengerjakan kedua tugas tersebut, ditambah konstribusi dari mengkonsep tajdîd fiqh yang relevan untuk saat ini, sehingga dapat dijadikan sebagai 
referensi tambahan untuk tajdîd di masa datang.

\section{Rekonstruksi Fiqh Sebuah Keniscayaan}

Untuk merekonstruksi fiqh, perlu adanya pemilahan istilah antara syariah, fiqh dan fatwa dalam perspektif Jaseer Audah, meskipun tidak semua 'ulama' sepakat dengannya. Menurut Jaseer, sebenarnya ada perbedaan antara syariah, fiqh dan fatwa. Syariah adalah wahyu yang diterima Nabi melalui malaikat Jibril as. Sedangkan fiqh adalah beragam kumpulan pendapat para fuqaha atas hasil pemahaman mereka sendirisendiri yang didasarkan pada al-Qur'an dan sunnah, melalui pendekatan dan metode yang berbeda-beda, di berbagai sisi kehidupan sepanjang sejarah Islam yang sudah lebih dari 14 abad. Adapun fatwa merupakan hasil penerapan dalil-dalil syariah dan fiqh pada kehidupan ummat hari ini yang selalu up to date. ${ }^{1}$ Hal ini memberikan pamahaman kepada kita bahwasannya tidak ada pendapat fiqh yang benar-benar bisa diyakini kebenarannya secara mutlak. Menurut Wahbah Zuhaily, dalam hukum islam ada sesuatu yang bersifat $t$ sawâbit dan mutaghayyirât, sebagai wujud keluwesan syariah yang memberi ruang berfikir bagi ulama juga untuk menyesuaikan dengan kemaslahatan dimanapun dan kapanpun.

Dinamika kehidupan mengharuskan untuk menerima dan juga memilah sesuatu yang dianggap baru. Dalam ranah fiqh, tajdîd diperlukan selama tidak berseberangan dengan nash syar' $i$ yang qath' $i$, yang bertujuan untuk kemaslahatan ummat bersama. Kebutuhan untuk merekonstruksi fiqh dianggap sebuah keharusan manakala terdapat kesulitan yang sangat dalam penerapannya. Upaya rekonstruksi ini sesuai dengan kaidah (almashaqqah tajlib al-taysîr) dan (idza dhâqa ittasa'a). Tajdîd juga harus dibatasi pada masalah-masalah yang baru yang tidak tercantum dalam nash. Disamping itu, tajdîd diperlukan juga pada masalah penggunaan istilah, seperti phografi yang dikenal sekarang dalam bahasa Arab dengan tashwîr. Jika istilah tashwîr dulu dengan sekarang berbeda, maka hukumnya pun berbeda antara tashwîr zaman

\footnotetext{
${ }^{1}$ Jaseer Audah, Maqasid al-Shari'ah Falsafah Li alTashri'I al-Islami (London; The International Institute Of Islamic Thought, 2007), h. 8
}

dulu dengan sekarang. Misalnya menghukumi haram dalam masalah photografi tidak bisa dibenarkan, alasannya karena pada zaman dahulu belum ada elektronik semacam photografi. Dalam hal ini pembaruan makna istilah dalam fiqh sangat diperlukan, sehingga menghasilkan hukum yang berbeda pula yang sesuai dengan dinamika perkembangan zaman. ${ }^{2}$

Harus diakui, bahwa ada beberapa produk fiqh yang saat ini dengan meminjam istilah Prof. Amin Abdullah "expire". Ini harus dipahami karena memang fiqh lahir dari sebuah pemahaman seorang mujtahid yang sangat terkait dengan kondisi, adat dan lingkungan dimana ia hidup. Misalnya, seperti apa yang telah dilakukan oleh Imam Syâfi'i yang mencoba menjembatani dua aliran besar saat itu, ahl al-ra'yi dan ahl al-hadîts. Buah dari upaya tajdîd-nya ini kemudian melahirkan metode baru dalam mengistinbat hukum sebagaimana tertuang dalam buku-bukunya terutama dalam al-Risâlah. ${ }^{3}$

Khalifah Sayyidina Umar Ibn 'Abdul 'Aziz ketika menjabat Gubernur di Madinah bersedia member keputusan hukum bagi gugatan penggugat bila ia bisa mengajukan dua orang saksi atau satu orang saksi disertai sumpah dari penggugat. Sumpah tersebut dimaksudkan untuk mengganti kedudukan saksi yang lain. Akan tetapi, setelah beliau menjabat khalifah yang berkedudukan di ibu kota Negara saat itu yaitu Syam, beliau enggan memberikan ketetapan hukum atas pengajuan formula saksi yang sama. Ketika ditanya tentang perubahan itu beliau menjawab; "orang madinah berbeda dengan orang Syam." Dalam hal ini masih banyak lagi contoh-contoh yang bisa kita temukan dalam literature-literature kitab sejarah, fiqh maupun hadis tentang hal semacam ini.

Salah satu doktrin Islam yang mendapat perhatian serius dan mempunyai dampak yang besar pada pola kehidupan dan cara berfikir ummat dari dulu hingga saat ini adalah fiqh. Sampai-sampai seorang pemikir

\footnotetext{
${ }^{2}$ Wahbah al-Zuhayli, Tajdîd Al-Fiqh Al-Islamy (Bairut: Dar Al-Fikr), h. 167-172

${ }^{3}$ http://pwkpersis.wordpress.com/2008/05/29/tajdid-alfiqh-why-not/ diakses tanggal 24 Januari 2010

${ }^{4}$ Abu Yasid, Islam Akomadif; Rekonstruksi Pemahaman Islam Sebagai Agama Universal (Yogyakarta: Lkis, 2004), h.118
} 
muslim dari Maroko Muhammad Abîd AlJâbirî berkomentar, "jika kita boleh menamakan peradaban Islam dengan salah satu produknya, maka kita harus mengatakan peradaban Islam adalah peradaban fiqh.", Pengakuan itu kiranya ada benarnya, Bahkan al-Habib Salim al-Shatiri dalam salah satu ceramahnya menegaskan bahwa ilmu agama Islam yang paling utama adalah fiqh. ${ }^{6}$ Dikatakan demikian, karena berdasarkan pada kuantitas dan kualitas perhatian umat Islam terhadap fiqh. Dari segi kuantitasnya karya fiqh banyak mendominasi, meski tidak bisa dikatakan terbanyak dalam kekayaan khazanah intelektual Islam. Sedangkan dari segi kualitas, fiqh mampu menaklukkan umat Islam di hadapan otoritasnya. Tidak satu pun gerakgerik umat Islam bisa lepas dari jeratan hukum fiqh.

Namun di sisi lain, sikap umat Islam yang sangat berlebihan terhadap fiqh tersebut ikut andil melahirkan aspek-aspek negatif. Umat Islam terlalu silau dengan berjibunnya karya-karya ulama fiqh klasik sehingga sebagian orang menganggap kewajiban kita 'cuma' menerapkannya saja. Fiqh menjelma bagaikan anak yang dimanja, sehingga tidak boleh disentuh apalagi dikritik. Akibatnya, fiqh yang awal-mulanya adalah ikhtiar pemahaman manusia yang dinamis terhadap problemproblem kemanusian melalui perspektif syariat Tuhan, enjelma menjadi pemahaman manusia yang otoriter. Tidak bisa dibedakan antara Kehendak Tuhan yang ideal dengan pemahaman manusia yang terbatas. Sikap demikian bukan hanya mambunuh kreatifitas, tapi juga semakin mengukuhkan fiqh sebagai doktrin Islam yang otoriter dan membendung kemajuan umat Islam. Maka dari itu Khaled, mengajak kita melakukan pembongkaranpembongkaran terhadap otoritarianisme dalam hukum Islam. Sebagai langkah awal, perlu memberi batasan yang tegas antara "yang otoritatif" dan "yang otoriter"; antara "kewewenangan" yang berbeda dari

\footnotetext{
${ }^{5}$ Idza jaza lana al -nusammi' al-hadlarah al-islamiyah bi ihdza muntajatiha fa'innahu sayakunu 'alayna alnaqûlu 'anha innaha hadlarah fiqh. Muhammad Abid Al-Jabiri, Takwin al- 'Aql al- 'Arabi (Beirut: Al-Markaz al-Tsaqafî al-'Arabî), h. 96

${ }^{6}$ Disampaikan di Pondok Pesantren Mambaus Sholihin Gresik sekitar bulan Januaru 2011
}

"kesewenang-wenangan" dalam diskursus hukum Islam" (the authoritative and the authoritarianin Islamic discourse). ${ }^{7}$

Di tengah deretan karya pembaruan fiqh di atas, karya seorang cendikiawan muslim Khaled Abou El Fadl patut mendapat sambutan hangat untuk dikaji dan dikritik. Di mana posisi karya-karya Khaled dalam diskursus pembaruan fiqh di atas melakukan pembaruan dalam ranah metodologis sekaligus tematis. Dalam karya-karyanya Khaled mengundang kita untuk melakukan pembaruan-pembaruan terhadap hal-hal mendasar dalam masalah metode/ epistemologi penetapan dan penggalian hukum (manhaj/ tharîqah itsbâth wa intinbath al-ahkam) seperti meninjau kembali pemahaman terhadap sumber-sumber primer hukum Islam yaitu al-Quran, Sunnah dan varian mekanisme ijtihad, qiyâs (analogi), ijma' (konsensus), mashalih al-mursalah, dll). Pada selanjutnya, metode tersebut, digunakan oleh Khaled sebagai pisau analisis untuk membedah beberapa tema aktual saat ini. Kebanyakan tema-tema yang sangat mengakar dan mempunyai dampak yang serius adalah tema yang berkaitan dengan persoalan jender.

\section{Pembaruan Hukum Islam}

Dalam beberapa dekade terakhir, muncul gerakan untuk melakukan "pembaruan fiqh" (tajdîd al-fiqh) maupun gagasan "fikih baru" (fiqh jadîd). Wacana pembaruan dalam hukum Islam ini paling tidak bisa dikategorikan menjadi dua macam, yaitu (1) pembaruan yang berangkat dari akar metodologis dan epistimologis. Pembaruan model ini lebih menitikberatkan pada rekonstruksi ilmu ushul fikih sebagai pijakan dasar ilmu fiqh. Beberapa karya penting ulama kontemporer yang patut menjadi rujukan adalah: Tajdîd al-Fiqh al-Islamî karya Dr. Jamaluddin Athiyah dan Dr. Wahbah Zuhayli, al-Tajdîd fì Ushul al-Fiqh karya Dr Hasan alTurabi, al-Fiqh al-Islamî fî Thariq al-Tajdîd karya Dr Muhammad Salîm al-'Awwa', Nahw Fiqh Jadîd karya Jamal al-Banna dan lain-lain.

\footnotetext{
${ }^{7}$ http://www.facebook.com/note.php?note id=19987790 $\underline{5389}$ Membongkar Otoritarianisme dalam Hukum Islam oleh Mohamad Guntur Romli pada 31 Oktober 2009 jam $11: 21$
} 
Disamping itu, ada juga beberapa buku yang secara khusus mengkaji tema maqashid al-syari'ah seperti Nadzariyah al-Maqâshid 'Indza al-Imam al-Syathibi karya Dr. Ahmad al-Raysuni, al-Maqashid al-'Ammah li alSyari'ah al-Islamiyah karya Dr Yusuf Hamid al-Alim, Nahw Taf'il Maqashid al-Syari'ah karya Dr Jamaluddin 'Athiyah, Maqashid alSyari'ah al-Islamiyah wa Makarimuha karya 'Allal al-Fasi, Maqashid al-Syari'ah karya Jaseer 'Audah, Maqâshid al-Syari'ah alIslamiyah karya Syekh Thahir bin Asyur dan lain-lain. Kedua, adalah pembaruan yang mengupas tema-tema fiqh terkait tinjau-ulang terhadap hukum fiqh. Karya yang mengupas pembaruan model kedua ini sangat banyak dan melebihi usaha pertama. Biasanya pemilihan tema fiqh didasarkan pada alasan kebutuhan yang darurat dan mendesak. Seperti pembahasan seputar masalah-masalah ekonomi, politik dan sosial yang dikaitkan dengan pembahasan fiqh. Ataupun masalahmasalah ibadah ritual seperti gagasan penyatuan antara zakat /pajak dan peninjauan ulang waktu haji oleh Masdar F Mas'udi, fatwa-fatwa kontemporer milik Dr. Yusuf alQaradlawi, tema Jihad oleh Dr Ramadlan alBûthî, dan lain-lain. Untuk sekedar mengingatkan, di Indonesia sendiri telah terbit sekumpulan pembaruan fiqh tematis yang menyulut kontroversi di mana-mana. Buku itu berjudul Fiqh Lintas Agama yang mengulas hukum-hukum relasi muslim dan non-muslim, seperti hukum nikah beda agama, mengucapkan salam, saling mendoakan, dan lain-lain.

Dalam salah karya terbaiknya Speaking in God's Name: Islamic Law, Authority and Women $^{8}$, Khaled Abou El Fadl menyajikan sebuah kerangka konseptual untuk membangun gagasan tentang toritas dan otoritarian dalam Islam. Pembahasan otoritas sangat penting karena tanpa otoritas maka kita akan beragama secara subjektif, relatif dan individual. Untuk itu perlu ada hal-hal yang baku (al-tsawâbit) dalam agama. El Fadl membangun konsep otoritas dalam Islam dengan doktrin Kedaulatan Tuhan dan Kehendak Tuhan.

\footnotetext{
${ }^{8}$ Khaled Abou El Fadl, Speaking in God's Name, Islamic Law, Authority, and Women (Oxford: Oneworld Publication, 2003), edisi bahasa Indonesia, Atas Nama Tuhan (Jakarta: Serambi, 2004)
}

Kehendak Tuhan dijelaskan melalui KalâmNya yang telah tertulis. Demikian juga Nabi, sebagai pemegang otoritas kedua setelah Tuhan melalui tradisinya (Sunnah) yang telah terkodifikasi. Pada konteks ini telah terjadi proses pengalihan dari 'suara' Tuhan dan Nabi menjadi teks-teks yang tertulis dalam al-Quran (mushaf) dan kitab-kitab Hadis.

Dihadapan kita saat ini tentu telah ada sekumpulan teks-teks yang dipandang mewakili 'suara' Tuhan dan Nabi. Kemudian yang menjadi pertanyaan, sejauh mana teksteks tersebut memiliki otoritas mewakili 'suara' Tuhan dan Nabi? Bagaimana kita memahami kehendak Tuhan dan Nabi melalui perantara teks-teks tersebut? Bagaimana bentuk aturan-aturan wakil Tuhan agar bisa menyampaikan kehendak Tuhan tanpa menganggap pendapatnya sebagai kehendak Tuhan? Untuk merespon pertanyaanpertanyaan tersebut, menurut Khaled kita harus memerhatikan tiga hal, yaitu: Pertama berkaitan dengan "kompetensi" (autentisitas). Kedua, berkaitan dengan "penetapan makna". Ketiga berkaitan dengan "perwakilan". 9 Tiga pokok persoalan tersebut telah menjadi tiga kunci bagi Khaled untuk memisahkan diskursus yang otoritatif dan otoriter dalam Islam.

Persoalan pertama mengenai kompetensi (autentisitas) adalah bagaimana kita mengetahui bahwa perintah tersebut benarbenar datang dari Tuhan dan Nabi-Nya. Teksteks yang memiliki kompetensi (autentisitas) dinilai sebagai teks-teks yang otoritatif, sedangkan teks-teks yang tidak memiliki kompetensi, tidak memiliki otoritas mewakili 'suara' Tuhan dan Nabi. Penggunaan teks-teks yang tidak otoritatif akan menjerumuskan manusia pada otoritarianisme, yaitu penganugrahan otoritas pada yang tidak otoritatif.

Dalam konteks kompetensi al-Quran, Khaled menggunakan asumsi berbasis iman bahwa al-Quran adalah firman-Tuhan yang abadi dan terpelihara kemurniannya. Kompetensi al-Quran tidak bisa diganggugugat. Maka dari itu, persoalan kompetensi (autentisitas) hanya berlaku pada Sunnah tidak

\footnotetext{
${ }^{9}$ Khaled Abou El Fadl, Speaking in God's Name, Islamic Law, Authority, and Women, h. 25-26
} 
pada al-Quran. Kompetensi Sunnah perlu dipertanyakan agar benar-benar otoritatif bisa mewakili 'suara' Nabi. Khaled sendiri dalam membahas kompetensi Sunnah menggunakan metodologi kritik hadis klasik (mushthalâh alhadits) dari kritik trasmisi (naqd al-sanad) dan kritik perawi ('ilm al-rijâl).

Namun yang perlu diperluas menurut Khaled adalah kajian hadis harus menyentuh realitas sejarah. Dalam pandangan Khaled menilai perawi dalam rantai periwayatan; bisa dipercaya atau tidak dipercaya, memang cukup membantu, tapi tidak meyakinkan. Maka dari itu Khaled ingin mengembangkan kajian hadis pada kritik redaksi hadis (naqd al-matan) yang memungkinkan seseorang mengkaji konteks sosio-historis hadis. Dan yang lebih penting lagi adalah, persoalan sesungguhnya bukan Nabi telah mengatakan atau tidak mengatakan sesuatu, tapi peran apa yang dimainkan Nabi dalam sebuah riwayat tertentu (the issue is not wether the Prophet said or did not say something but what the role did the Prophet play in a particular report). ${ }^{10}$

Pemahaman peran sosok Nabi itu akan melahirkan perbedaan fungsi pada Sunnah. Jika Nabi melakukan sebagai sosok manusia biasa, maka Sunnah tidak memiliki otoritas sebagai sumber hukum (al-sunnah ghayr tasyri'iyyah). Sebaliknya, jika Nabi memerankan sebagai utusan Tuhan, maka Sunnah itu memiliki otoritas untuk diikuti (al-sunnah altasyri'iyyah). Menurut Jaseer 'Audah, tidak setiap hadis Nabi mempunyai makna tasyri'. Jaseer menyimpulkan bahwa hadis Nabi mempunyai dua belas makna bila ditinjau dari segi maqâsid al-syaria'h, yaitu tasyri', fatwa, penyelesaian sengketa (posisi Nabi sebagai hakim bagi kaum muslimin), 'imârah, alirshad, musalahah, isharah kepada almustashîr, nasihat, penyempurnaan keadaan jiwa atau hati, tujuan pengajaran hakikat yang luhur, al-ta'dîb dan yang terakhir tidak ditujukan untuk kepentingan pengajaran. ${ }^{11}$ Selain itu Khaled juga menegaskan perlu membedakan kriteria Hadis Ahad dengan Hadis Mutawatir karena keduanya memiliki perbedaan kadar ororitas dalam proses

\footnotetext{
${ }^{10}$ Khaled Abou El Fadl, Speaking in God's Name, Islamic Law, Authority, and Women, h. 87-88

${ }^{11}$ Jaseer Audah, Maqasid As Philoshophy Of Islamic Law , h. 234-236
}

legislasi. Hadis Mutawatir memiliki kadar kompetensi (autentisitas) lebih kuat. ${ }^{12}$

Seorang pemikir liberal Mesir Jamal al-Banna memberikan komentar lebih jauh ketika menjelaskan persoalan al-tsubût (autentisitas/ orisinilitas) dengan al-hujjiyah (kompetensi) ketika membahas Sunnah. Persoalan al-tsubût berkenaan dengan orisinilitas transmisi Sunnah. Menurut Gamal, dalam masalah ini, Sunnah memiliki problem serius. Penulisan sunnah dilarang waktu Nabi, dan Sunnah baru dikodifikasi pada paruh abad kedua Hijriah tepatnya pada era Khalifah Sayyidina Umar bin Abd Aziz. Oleh karena itu, Gamal sangat berhati-hati dalam menggunakan Sunnah. Menurutnya hadis palsu lebih banyak dari hadis yang asli (shahîh). Sedangkan hadis ahad lebih banyak daripada hadis yang mutawatir. Ketika berbicara mengenai hujjiyah (kompetensi) Sunnah, hadis-hadis tersebut harus disesuaikan dengan standarisasi Al-Quran sebagai satu-satunya sumber hukum Islam yang tetap dan akurat. Hadis-hadis yang melawan otoritas al-Quran tidak dianggap hadis-hadis otoritatif lagi.

Sedangkan persoalan kedua mengenai penetapan makna, bagaimana kita menetapkan makna dari Kehendak Tuhan itu? Seperti yang telah dimaklumi bahwa Tuhan telah menggunakan sarana teks untuk menyampaikan kehendak-Nya, sedangkan teks tidak bisa berbicara sendiri, dia butuh manusia untuk berbicara. Dalam hal ini, Manusia dihadapan pada teks adalah 'lidah' sebagai artikulatur sekaligus interpreter teks.

\footnotetext{
12 Hadis Ahad diriwayatkan melalui mata rantai periwayatan tunggal sedangkan Hadis Mutawatir diriwayatkan melalui beberapa mata rantai periwayatan dan diasumsikan hadis mutawatir tidak mungkin dipalsukan. Namun 'Abd Razzaq Id dalam bukunya Sadnah Hayâkil al-Wahm, Naqd al-'Aql al-Fiqhî: (Beirut: Dar al-Thalî’ah, 2003), h. 36-40, menyangsikan keberadaan hadis-hadis mutawatir itu. Karena peristiwaperistiwa besar dalam sejarah Nabi; seperti usia Nabi, hari/ tanggal wafat dan pemakaman Nabi, serta hari pembaiatan Abu Bakar, yang seharusnya setiap sahabat mengetahui secara pasti namun realitanya tidak ada kesepakatan riwayat di antara sahabat Nabi. Jika peristiwa-peristiwa besar itu saja tidak diriwayatkan melalui hadis-hadis mutawatir maka sabda-sabda Nabi yang lain-yang belum tentu didengar oleh banyak sahabat - sangat mustahil disebut hadis mutawatir. 'Abd Razaq juga menyebut lebih dari 300 khutbah jumat Nabi yang semestinya menjadi hadis-hadis mutawatir hilang.
} 
Memposisikan manusia dalam subjek teks, bukan tanpa masalah, melainkan sebaliknya. Karena tidak jarang, kita jatuh pada "pembunuhan teks" dan "pelacuran hermeneutika" yang merampas kesucian (autentisitas) teks. Ketika semua berhak bersetubuh dengan teks tanpa kewewenangan, tidak ada yang bisa menjamin teks tersebut ditafsirkan sebebas-bebasnya. Dalam posisi ini, teks akan ditelanjangi dari autentitas, makna dan tujuannya. Dalam pandangan Khaled, sikap tersebut merupakan tindakan sewenangwenang yang menyuburkan penafsiran otoriter.

Bagaimana menjaga kesucian (autentisitas) teks ini, agar tidak mudah 'disetubuhi' dan selaras dengan makna aslinya? Menurut Khaled untuk menjawab persoalan ini kita membutuhkan keseimbangan kekuatan yang harus ada antara maksud teks, pengarang dan pembaca (balance of power between the author, reader and text). Penetapan makna berasal dari proses yang kompleks, interaktif, dinamis dan dialektis antara ketiga unsur di atas (teks, pengarang dan pembaca). Salah satu maksud tiga unsur itu tidak ada yang mendominasi. Penafsiran yang tepat adalah penafsiran yang menghormati peranan, otonomi dan integritas teks. Menghormati otonomi teks bertujuan menghindari kooptasi dan otoritarianisme pembaca terhadap teks sehingga teks bisa ditafsirkan sebebarbebasnya. Maka dari itu, Khaled menegaskan gagasan tentang teks yang terbuka (the open text). Al-Qur'an dan Sunnah-dengan meminjam istilah Umberto Eco, merupakah "karya yang terus berubah" ("works in movement"). Keduanya adalah karya yang membiarkan diri mereka terbuka bagi berbagai strategi interpretasi (they are works that leaves themselves open to multiple interpretative strategies). ${ }^{13}$

Sedangkan sikap otoriter adalah proses pemasungan teks sehingga teks tidak bisa leluasa bergerak dan berinteraksi dengan keragaman makna. Dalam bahasa Khaled, "Authoritarianism is the act of "locking" or captivating the Will of Divine or the will of the tex into the spesific determination, and then presenting this determination as inevitable, final, and conclusive" (Otoritarianisme adalah

\footnotetext{
${ }^{13}$ Khaled Abou El Fadl, Speaking in God's Name, Islamic Law, Authority, and Women, h. 146
}

tindakan "mengunci" atau mengurung Kehendak Tuhan atau kehendak teks, dalam sebuah penetapan tertentu, dan kemudian menyajikan penutupan tersebut sebagai sesuatu yang pasti, absolut dan menentukan. ${ }^{14}$ Pada posisi ini pembaca hanya akan melahirkan penafsiran yang otoriter, bahkan melahirkan fanatisme yang mengkultuskan pada penafsiran-penafsiran sehingga menganggap hasil penafsirannya memiliki kompetensi yang sama dengan teks asal (al-Quran dan Sunnah).

Meskipun siapapun bebas untuk menjadi "wakil khusus Tuhan" yang menginterpretasi ulang teks, namun patut dipertimbangkan lima syarat yang ditawarkan oleh Khaled sebelum memasuki wilayah penfsiran, yaitu: (1) Kejujujuran (honesty), bahwa seorang wakil Tuhan harus bisa dipastikan kejujurannya, sehingga dapat dipercaya; (2) Kesungguhan (diligence), bahwa seorang wakil khusus harus dipastikan telah mengerahkan segenap upaya rasional untuk menemukan dan memahami Kehendak Tuhan; (3) Kemenyeluruhan (comprehensiveness), bahwa seorang wakil khusus harus dipastikan telah melakukan penyelidikan secara menyeluruh untuk memahami Kehendak Tuhan; (4) Rasionalitas (reasonableness), bahwa seseorang wakil khusus dipastikan telah melakukan upaya penafsiran dan menganalisis perintah-perintah Tuhan secara rasional; (5) Pengendalian diri (self-restraint), bahwa memiliki kerendahan hati dan pengendalian diri dalam menjelaskan Kehendak Tuhan. Seorang wakil harus memiliki kewaspadaan untuk menghindari penyimpangan atas peran Tuhan, berarti dia harus mengenal batasan peran yang menjadi haknya saja. Seorang wakil khusus jika tidak memiliki syarat di atas maka akan mudah melakukan pemahaman dan tindakan yang otoriter dengan mengatasnamakan Tuhan. ${ }^{15}$

\section{Rekontruksi Makna Ijtihad}

Teks (al-Qur'an dan al-Sunnah) tetap bebas, terbuka, dan otonom sebagaimana yang pernah disampaikan oleh Farid Esack dengan memahami al-Quran sebagai "pewahyuan

\footnotetext{
${ }^{14}$ Khaled Abou El Fadl, Speaking in God's Name, Islamic Law, Authority, and Women, h. 93

${ }^{15}$ Khaled Abou El Fadl, Speaking in God's Name, Islamic Law, Authority, and Women, h. 54-56
} 
progresif." Tuhan yang Maha Hidup terlibat aktif dalam urusan dunia dan umat Islam. Salah satu manifestasinya adalah mengutus para nabi sebagai instrumen pewahyuan progresif-Nya. Karakteristik al-Quran juga bersifat progresif seperti proses turunya al-Qur'an secara bertahap (tadriji). ${ }^{16}$ Suatu teks tentu memiliki makna tersendiri, begitupula pembacanya yang bersifat subjektif untuk melahirkan makna lain. Kemudian yang menjadi pertanyaan, bagaimana relasi dialektis dua makna tersebut? Terkait relasi tersebut Khaled Abou El Fadl tidak menjelaskan lebih lanjut, kecuali hanya memberikan kaidah "perimbangan kekuatan" antara pengarang yang diwakili teks dengan pembaca. Untuk itu penulis ingin menyajikan pendapat Nashr Hamid Abu-Zayd dalam bukunya Naqd al-Khithâb al-Dîni tentang perbedaan "makna statis" dan "makna progresif." Dalam hal ini Nashr Hamid membedakan arti "historis-orisinil" teks yang disebut ma'nâ (pengertian) dan arti "realistasmodern" teks yang disebut maghza (signifikansi).

Menurut Nashr Hamid Abu-Zayd, perbedaan makna dan signifikansi terletak pada dua aspek. Pertama, "makna" adalah pemahaman terhadap teks yang berasal dari konteks internal bahasa (al-siyaq al-lughawi al-dhakhili) dan konteks eksternal sosiokultural (al-siyaq al-tsaqâfi al-ijtima'i alkhariji). Sedangkan "signifikansi" adalah pemahaman terhadap teks sesuai dengan kondisi kekinian melalui perspektif pembaca. Hubungan antara makna dan signifikansi seperti dua mata uang yang tidak bisa dipisah. Bahkan, "signifikansi" lahir dari pemahaman kita terhadap makna asal teks-teks tersebut. Kedua, "makna" bersifat statis-relatif (al-tsabit al-nisbi), yaitu karena ia merupakan makna asli (otonom) teks sehingga terus menyertai teks tersebut, sehingga memiliki "keterbatasan" ruang dan waktu. Sedangkan "signifikansi" terus bergerak mengikuti perputaran dan perubahan cakrawala pembaca. ${ }^{17}$

Sebuah nash tidak ada artinya jika tidak 'digauli' oleh akal untuk difahami dan ditafsiri sesuai dengan kondisi realitas mujtahid. Maka

\footnotetext{
${ }^{16}$ Farid Esack, Membebaskan Yang Tertindas (Bandung: Mizan, 2000), h. 87

${ }^{17}$ Nashr Hamid Abu-Zayd, Naqd al-Khithab al-Dini (Cairo: Madbuli, 1995), h. 221
}

sudah sepatutnya kita menkaji makna ijtihad setelah membahas tentang nash. Karena hanya dengan ijtihad itulah suatu nash tidak hanya menjadi sebuiah bangunan materi yang mati tetapi ia menjadi hidup mengikuti perubahan zaman. Dalam hal ini, kedudukan nash bagaikan jasad sedangkan ijtihad bagaikan ruh.

Ijtihad pada dasarnya adalah usaha nalar (juhd fikri) untuk mencari solusi dengan suatu hukum yang proporsional. Realitas umat selalu muncul silih berganti, sehingga produk hukum yang dikatakan fiqh sebenarnya adalah ijtihad. Hal ini merupakan konsekuensi dari penolakan terhadap skripturalisme pada nash. Sikap yang berkutat pada nash akan mengantarkan stagnasi pemikiran yang dengan sendirinya akan menutup pintu ijtihad. Padahal sesungguhnya tidak seorang pun yang bisa menutup pintu ijtihad. Bahkan ijtihad merupakan kebutuhan umat Islam sepanjang masa seperti yang telah disinyalir oleh Nabi Muhammad: "Sesungguhnya Allah akan mengutus dalam umat (Islam) ini stiap awal satu abad, orang yang memperbarui agama mereka." Jadi, agama butuh pembaharuan agar tetap eksis bagi umatnya. Tentu yang diperbaharui di sini adalah pemahamannya bukannya teks yang merupakan sumber dari agama itu sendiri.

Salah satu format ijithad yang sering dilegimitasi oleh ulama klasik adalah qiyâs. Namun seperti yang sudah disinggung, peran akal di dalam qiyâs hanya terbatas untuk mencari illat yang banyak berkutat pada lafal. Sedangkan landasan dasar qiyâs berupa kejadian yang sudah ada hukumnya dan bersifat terbatas dengan kejadian serupa dan baru. Hal ini menurut $M$. Abid al Jabiri merupakan penyebab tertutupnya pintu ijtihadi. ${ }^{18}$ Dikatakan demikian, karena proses ijtihad hanya berputar dalam lingkaran lafal dan illat yang sempit.

Sudah waktunya kita merekontruksi makna ijtihad dan bukan sekedar ajakan membuka pintu ijtihad. Artinya ijithad tidak hanya terbatas mencari illat dalam qiyâs, namun kita harus mencari alternatif yang sifatnya lebih komprehensip. Kita harus

\footnotetext{
${ }^{18}$ Abid al Jabiri, al Din wa al Daulah wa Tatbiq al Syariah. http://www.mizan-

poenya.co.cc/2010/08/kritik-nalar-fiqh-menuju-fiqhyang.html
} 
mengadakan reinterpretasi makna ijtihad. Hal ini mengharuskan kita untuk menggunakan maqashid syariah sebagai metode pendekatan system sebagaimana yang ditawarkan oleh Jaseer 'Audah, sehingga akal dalam ijtihad punya andil yang semestinya.

Kenapa harus akal? Inilah pertanyaaan yang telah dicoba dijawab oleh Imam Syatibi. Ia menegaskan bahwa ijtihad model lama sudah tidak mampu lagi menjawab tantangan. Sebagai gantinya kita harus mengadakan ta'shil al ushûl dengan menjadikan maqashid syariah sebagai poros ijtihadi ta'shil ushûl mempunyai arti bahwa pembaharuan tidak hanya dalam furu' atau juziyyat, lebih dari itu pembaharuan harus dilakukan dari akarnya. Meskipun Jamal al Bana menganggap pemikiran Imam Syatibi kurang orisinil. ${ }^{9}$ Namun itu adalah sebuah gebrakan yang patut dicontoh. Terbukti Muhammad Abduh sempat mengusulkan kitab Al Muwâfaqat untuk dijadikan muqarrar dalam bidang ushul fiqh.

$$
\text { Pernyataan }
$$

tersebut

telah

diaktualisasikan oleh Jaseer 'Audah dengan memperluas cakupan dari maqâsid al-shari'ah klasik (menurut al-Syatibi dan dipopulerkan oleh al-Ghazali, yaitu menjaga agama, jiwa, harta, akal dan keturunan $)^{20}$ menuju maqâsid al-shari'ah yang mampu menjawab tantangan global kekinian. Perluasan untuk bergeser dari hukum berorientasi individual kepada orientasi ummat manusia secara umum. Hifdzu al-nasl (perlindungan keturunan) diperluas menjadi hifdzu al-usrah, hifdzu al-'aql (perlindungan akal) menjadi perlindungan berfikir ilmiyah atau perwujudan semangat mencari ilmu pengetahuan, hifdzu al-nafs (perlindungan jiwa) menjadi hifdzu al-karâmah al-insaniyah (perlindungan kehormatan manusia), hifdzu aldîn (perlindungan agama) menjadi hifdzu hurriyatu i'tiqâd (perlindungan kebebasan beragama), hifdzu al-mal (perlindungan harta), menjadi perwujudan solidaritas social. ${ }^{21}$

\footnotetext{
${ }^{19}$ Letak kekuarang-orisinilan ini menurut Jamal al Banna terlihat dalam tambal sulam yang dilakukan Imam Syatibi dalam maqashid Syariah sebagai justifikasi terhadap perintah Tuhan. Imam Syatibi tidak memasuki pembahasan sebenarnya yaitu masalah hikmah dan masalahah yang diperdebatkan oleh al Thufi dan al Izzu ${ }^{20}$ Abu Ishaq al-Syatibi, al-Muwafaqat fi Ushul al-Fiqh (Bairut; Dar al-Kutub al-'Ilmiyah, t.t), jilid. 1.

${ }^{21}$ Jaseer Audah, Maqasid As Philoshophy Of Islamic Law, h. 3-4
}

Aksentuasi ijithad yang dilandaskan pada maqâsid al-shari'ah bisa kita temukan akarnya dalam ijtihad sayyidina Umar ibn Khatab. Dalam suatu riwayat, sayyidina Umar tidak melaksanakan potong tangan pada pencuri di masa paceklik, tidak membagikan ghanimah pada yang berhak tapi dialihkan ke baitul mâl, tidak mendistribusi zakat kepada golongan muallaf, dan membebaskan jizyah pada seorang yahudi yang sudah tua renta. Ijitihad-ijtihad yang disebut fiqh sayyidina Umar merupakan bentuk implementasi ijtihad yang berporos pada maqâsid syariah. Jika kita analisa lebih lanjut melalui epistemologi ijtihad maslahah dan contoh yang diberikan sayyidina Umar, maka akan segera kita sadari bahwa ijtihad model tersebut justru akan lebih memuat nilai-nilai humanis sehingga mampu memecahkan problem-problem yang sedang melanda umat.

Di dalam ijtihad fiqhinya Qardhawi, ${ }^{22}$ telah berhasil membuat sebuah formulasi baru dalam memperlakukan fiqh, terutama ketika ia berhadapan dengan persoalan-persoalan kontemporer. Diantara formula yang dibangun adalah mengenai perlunya dibangun sebuah fiqh baru (fiqh jadîd) yang akan dapat membantu menyelesaikan persoalan-persoalan baru umat. Meskipun demikian, yang dimaksud dengan figh, seharusnya tidak hanya terbatas pada persoalan-persoalan yang berkaitan dengan hukum-hukum juz' $i$ yang diambil dari dalil-dalil terperinci (tafshili) seperti persoalan-persoalan thaharah, shalat, zakat dan lain sebagainya, bukan pula hanya merupakan sebuah sistem ilmu dalam Islam, melainkan lebih dari itu, seraya mengutip alGhazali, yang menyatakan bahwa fiqh adalah sebuah pemahaman yang komprehensif terhadap Islam, yaitu sebagai al-fahm (pemahaman).

Adapun fiqh baru yang berusaha dibangun antara lain: (1) Keseimbangan (fiqh al-Muwazanah), yaitu sebuah metode yang dilakukan dalam mengambil keputusan hukum, pada saat terjadinya pertentangan dilematis antara maslahat dan mafsadat atau antara kebaikan dan keburukan, karena menurutnya, di zaman kita sekarang ini sangat sulit mencari sesuatu yang halal seratus persen atau yang

\footnotetext{
${ }^{22}$ http://imadu.multiply.com/journal/item/5 . (diakses 5 oktober 2011)
} 
haram seratus persen. Menurutnya, dengan menggunakan sistem fiqh seperti ini kita akan dapat memahami bahwa pada kondisi seperti apakah sebuah kemudaratan kecil boleh dilakuakan untuk mendapatkan kemaslahan yang lebih besar, atau kerusakan temporer yang boleh dilakukan untuk mempertahankan kemaslahatan yang kekal, bahkan kerusakan yang besar pun dapat dipertahankan jika dengan menghilangkannya akan menimbulkan kerusakan yang lebih besar. (2) Fiqh realitas (Fiqh Waqi'i), yaitu sebuah metode yang digunakan untuk memahami realitas dan persoalan-persoalan yang muncul di hadapan kita, sehingga kita dapat menerapkan hukum sesuai dengan tuntutan zaman. (3) Fiqh prioritas (Fiqh al-Aulawiyat), yaitu sebuah metode untuk menyusun sebuah sistem dalam menilai sebuah pekerjaan, mana yang seharusnya didahulukan atau diakhirkan. Salah satunya adalah bagimana mendahulukan ushûl dari furu', mendahulukan ikatan Islam dari ikatan yang lainnya, ilmu pengetahuan sebelum beramal, kualitas dari kuantitas, agama dari jiwa serta mendahulukan tarbiyah sebelum berjihad. (4) Fiqh al-Maqashid al-Syari'ah, yaitu sebuah fikih yang dibangun atas dasar tujuan ditetapkannya sebuah hukum. Pada teknisnya, metode ini ditujukan bagaimana memahami nash-nash syar'i yang juz'i dalam konteks maqashid al-Syari'ah dan mengikatkan sebuah hukum dengan tujuan utama ditetapkannya hukum tersebut, yaitu melindungi kemaslahatan bagi seluruh manusia, baik dunia maupun akhirat. Ibn Qayyim yang mengatakan, bahwa prinsip utama yang menjadi dasar ditetapkannya syari'ah adalah kemaslahatan bagi seluruh umat manusia. Oleh karena itu, maka seluruh kandungan syari'ah selalu berisi keadilan, kasih sayang Tuhan dan hikmah-Nya yang mendalam. Dengan demikian, segala sesuatu yang di dalamnya mengandung kelaliman, kekejian, kerusakan dan ketidakbergunaan, maka pasti ia bukanlah syari'ah. (5) Fiqh perubahan (Fiqh al-Tagyîr), yaitu sebuah metode untuk melakukan perubahan terhadap tatanan masyarakat yang tidak Islami dan mendorong masyarakat untuk melakukan perubahan tersebut.

Disamping itu, kontribusi lain yang diberikan Qardhawi dalam bidang fiqh adalah bagaimana mencairkan kejumudan umat Islam dalam menghadapi zaman. Menurutnya, salah satu penyebab kejumudan tersebut adalah berhentinya kreativitas umat dalam berijtihad yang merupakan dapur utama kemajuan mereka. Dari masa ke masa, persoalan umat selalu berkembang, terutama setelah terjadinya inovasi-inovasi baru dalam bidang sains dan teknologi, sementara seperti kita fahami bersama bahwa jumlah ayat al-Quran dan hadits nabi, sampai kiamat mustahil akan bertambah. Oleh sebab itu, tidak ada cara lain untuk menjawab persoalan-persoalan tersebut kecuali melalui jalan ijtihad yang didasarkan pada prinsip-prinsip utama ajaran Islam.

Menurut Prof. Amin Abdullah, setidaknya ada dua pilar penyangga yang sesungguhnya dapat dimanfaatkan untuk membangkitkan kembali semangat ijtihad seperti diurai dimuka dan mengurai benang kusut yang membelenggu dinamika pemikiran Islam pada umumnya dan pemikiran hukum Islam khususnya. Dua pilar dimaksud adalah pilar normativitas dan historisitas. Pilar normativitas diperoleh dari teks al-Qur'an, surat Yusuf ayat 76, yang menyatakan dengan tegas bahwasanya "wa fauqa kulli dzi 'ilmin ali." Makna ayat tersebut penulis terjemahkan secara bebas bahwa di atas setiap orang, kelompok, organisasi atau institusi keagamaan yang merasa pandai, mesti ada orang, kelompok, organisasi, atau institusi keagamaan lain yang lebih pandai lagi."

Dari ayat tersebut dapat dipahami bahwa tidak ada finalitas dalam beragama. Petunjuk al-Qur'an ini secara tegas sangat bernuansa hermeneutis, sekaligus menepis anggapan sementara kalangan yang meragukan pendekatan hermeneutik dalam studi keislaman. Tampak sekali bahwa adanya ruang relativitas dalam budaya Islam dimanapun mereka berada. Ruang relativitas tersebut sangatlah diperlukan untuk menghidupkan kembali semangat mengoreksi kesalahan pemahaman, keyakinan, praktik-praktik ajaran agama, termasuk fatwa-fatwa keagamaan yang barangkali tidak sesuai dengan ruh ajaran alQur'an dan as-Sunnah itu sendiri.

Pilar kedua diperoleh dari historisitas praktik budaya intelektual Muslim sepanjang abad. Kalimat yang biasa dikutip oleh penulis dan pengarang Muslim di bagian akhir 
tulisannya "wa Allahu a'lam bi as-sawab" (Dan Allahlah yang lebih Mengetahui yang terbenar). Meskipun ungkapan ini sangat bernuansa hermeneutis, namun disini perlu penafsiran dan pemaknaan baru. Dikatakan demikian karena seringkali para penulis yang menggunakan prasa ini, dalam bermasyarakat sikap intelektualnya masih juga cenderung otoriter-angkuh. Kalimat ini menunjukkan bahwa setiap keputusan hukum yang diklaim pasti oleh pembuatnya sesungguhnya belum tentu dapat memenuhi rasa keadilan pemohonnya. Karena benturan antara keduanya yang sulit dikompromikan, intelektual Muslim lalu buru-buru bersandar kepada Tuhan sebagai penjamin terakhir kepastian dan keadilan. Sampai disini memang bagus, tetapi itu lebih cocok untuk era klasik yang menepikan dimensi sosiologis-antropologis-psikologis manusia.

Pada era modern dan lebih lagi era postmodern, untuk mendekatkan "rasa keadilan" (dalam kasus ini adalah penafsiran bias gender dan kasus-kasus lain sejenis) dan "kepastian hukum" (fatwa-fatwa yang dikeluarkan oleh CRLO yang dianggap final) haruslah melibatkan partisipasi seluruh masyarakat penafsir (community of interpreters). Dalam prosedur kerjanya, selain menggunakan bukti-bukti teks yang tersedia, juga memanfaatkan pengalaman kulturalsosiologis, mempertimbangkan kebiasan dan perangai psikologis manusia, mencermati nilainilai fundamental secara filosofis, dan kemajuan ilmu pengetahuan. Tanpa melibatkan sekelompok masyarakat penafsir dari berbagai latar belakang keilmuan, agaknya hukum Islam akan mudah terjebak pada authoritarianism, sehingga akan menghadapi tantangan serius pada era kontemporer.

\section{Memahami Fiqh Dengan Semangat Komprehensif-Progresif-Objektif}

Menurut Jaseer, sekarang ini penerapan produk fiqh selalu ikhtizaliyyan bukannya shumuliyyan, harfiyyan bukannya akhlaqiyyan, ahadiy al-bu'di bukannya ahadiy al-ab'ad. ${ }^{23}$ Sedikit ahli hukum yang memperhatikan batasan dari pendekatan reduksi dan atomism yang mana metode ini biasa digunakan oleh

\footnotetext{
${ }^{23}$ Jaseer Audah, Maqasid al-Shari'ah Falsafah Li alTashri'I al-Islami, h. 11
}

kelompok fundamental. Fakhr Al-Din Al-Razi meringkas beberapa perbedaan alasan para ahli hukum tentang kenapa dalil al-khitab dari sebuah teks hanya bersifat zanni dengan beberapa alasan: ${ }^{24}$ (1) Ada kemungkinan hukum yang kita adopsi berasal dari sebuah teks tunggal sudah dibatasi oleh suatau keadaan tertentu; (2) Ada kemungkinan bahwa ungkapan dari teks tunggal tersebut mempunyai makna majaz; (3) Referensi bahasa kita adalah dari ahli bahasa, sehingga setiap orang mempunyai kemungkinan untuk salah; (4) Gramatika bahasa arab disampaikan kepada kita melalui syair-syair arab kuno dengan jalur riwayat ahad; (5) Sangat dimungkinkan satu kata atau lebih dari sebuah teks mempunyai banyak makna atau tafsir; (6) Ada kemungkinan satu kata atau lebih dari sebuah teks maknanya sudah dirubah, dan pada waktu selanjutnya yang merubah adalah makna awal yang dirubah tadi; (7) Ada kemungkinan terdapat makna tersembunyi dari sebuah ungkapan yang kita tidak faham; (8) Boleh jadi hukum yang kita pertimbangkan dari sebuah teks tunggal sudah di mansûkh tanpa sepengetahuan kita; (9) Boleh jadi hukum yang kita pertimbangkan dari sebuah teks tunggal berlawanan dengan logika kebenaran.

Disamping itu, akal adalah sarana kita untuk memastikan keabsahan dari sebuah hadis itu sendiri. Dikatakan akal memiliki kedudukan lebih tinggi daripada hadis, karena tanpa akal nash tidak dapat difahami. Karenanya kita seharusnya mengikuti akal untuk menentukan kebenaran pada tiap kasus, bukannya mengikuti dalil ilmu kebahasaan dari sebuah teks. Di sini Jaseer ingin menambahi tiga poin dari sembilan poin di atas: (1) Ada kemungkinan sebuah teks mempunyai makna yang bertentangan dengan teks lainnya, sehingga teks semacam ini biasa dikenal dengan istilah al-nushûs al-muta'aridah. (2) Ada jarak yang sangat memungkinkan terjadinya kesalahan dalam penyampaian hadis ahad, yang mana hadis Nabi sangat banyak yang diriwayatkan secara ahad; (3) Ada jarak yang sangat memungkinkan terjadinya interpretasi dari setiap teks tunggal, sehingga mempengaruhi cara pandang kita dalam

\footnotetext{
${ }^{24}$ Muhammad Ibn 'Umar al-Razi, al-Mahsul, ed. Taha Jabir al-Alwani (Riyadh: Imam Muhammad University Press, 1400 H), jilid. 1, h. 547-573
} 
memahami makna atau maksud dari sebuah hadis. $^{25}$

Dari paparan diatas, seorang faqîh perlu kiranya memperluas pandangannya untuk memperdalam keluasan ilmunya, terutama sebelum mengeluarkan fatwa yang sangat berpengaruh pada masyarakat. Maka dari itu, seorang faqîh tidak bisa membuat produk hukum hanya dengan bersandar pada satu dalil baik dari al-Qur'an maupun hadis untuk dibuat hujjah.

\section{Ranah Ijtihad}

Wahbah Zuhayli menegaskan bahwa tidak diperbolehkan seorang mujtahid berijtihad dalam masalah yang sudah terdapat nash (sebagian besar ulama' mengartikan nash dengan redaksi teks al-Qur'an dan al-Sunnah) yang sudah qath' $i$, seperti kewajiban shalat, puasa, haji, zakat dan lain-lain. Adapun ruang ijtihad bagi seorang mujtahid hanya terbatas pada wilayah yang tidak terdapat nash sama sekali dari al-Qur'an, hadis maupun ijma' ulama' yang tidak ditentang oleh satupun muslim. $^{26}$ Menurut Zuhayli, yang dimaksud nash dalam kaidah la ijtihada fi ma fìhi nash adalah nash yang bersifat qath'I, sedangkan lafal yang bersifat zhanni merupakan ruang ijitihad manusia. Pemikiran semacam ini tidak bisa dibenarkan secara mutlak, bahkan dianggap sebagian kelompok keliru. Pemikiran ini dikuatkan oleh perkataannya Imam Ali ra: "Al-Quran mengandung banyak makna(hammal aujuh), Al-Quran adalah tulisan di antara dua sampul yang tidak bisa berbicara, yang berbicara hanyalah orangorang." Kata-kata Imam Ali ini merupakan kunci interaksi teks Al-Quran maupun hadis. Kegagalan dalam memegang kunci ini berarti kegagalan pula dalam manhaj ijtihad. Hal ini dikuatkan oleh beberapa ijtihad Sayyidina umar ibn al-Khattab dan 'Sayyidina umar ibn 'Abdul 'Aziz seperti contoh yang telah disebutkan diatas.

Masih berkenaan dengan nash, Jamal al Banna melihat bahwa dalam tataran praktisnya, ijtihad sebenarnya memerlukan eksplorasi makna dalam nash. Apapun tingkat kejelasan

\footnotetext{
${ }^{25}$ Jaseer Audah, Maqasid As Philoshophy Of Islamic Law, h. 198

${ }^{26}$ Wahbah al-Zuhayli, Tajdîd Al-Fiqh Al-Islamy (Bairut: Dar Al-Fikr), h. 190-19
}

lafal masih memerlukan penggunaan nalar. Kaidah la ijtihada ma al nash sebenarnya merujuk pada reduksi (ikhtizâl) hukum dalam bentuk qiyâs yang bersifat penjelas hukum (muzhîr) bukan pencipta hukum (munsyi'). Jika demikian berarti ia bukanlah ijtihad sebenarnya seperti apa yang telah dilakukan oleh Muaz bin Jabal. $^{27}$

Terdapat kelompok ulama' yang mempunyai perspektif lain dari yang sudah kita tulis, yaitu pemahaman nash sebagai teks yang sudah ditulis oleh para ulama klasik. Diantara teks karya ulama, ada yang diklasifikasikan mu'tabarah dan ghair mu'tabarah. Kenyataan bahwa teks-teks yang sesuai dengan kelompoknya dimasukkan sebagai mu'tabarah dan yang tidak sesuai dimasukkan dalam lingkaran ghair mu'tabarah. Corak pemikiran ini berakar pada sisitem taklid karena kepercayaan masa ijtihad sudah tertutup. Artinya ada asumsi yang berkembang bahwa sekarang tidak ada orang yang mumpuni dan mampu memenuhi syarat-syarat ijtihad yang telah digariskan oleh ulama klasik, sehingga satu satunya jalan adalah hanya mengikuti hasil ijtihad yang sudah dicapai oleh ulama zaman dahulu. Konsekuensi dari pemikiran tersebut adalah adanya ketergantungan pada teks-teks dalam kitab turats untuk menjawab problematika modern umat.

Hingga saat ini, tradisi yang menyandarkan pada kitab-kitab turats masih banyak berlaku di Indonesia terutama di sebagian pondok pesantren dan dalam forum bahsul masâil yang dijadikan rujukan umat dalam bidang hukum. Apabila tidak ditemukan nash dalam permasalahan yang ada, maka jalan selanjutnya adalah menganologikan permasalahan yang tidak ada hukumnya dengan permasalahan yang sudah ada hukumnya dalam aqwâl pada ulama karena ada kesamaan illat. Dalam hal ini, tidak boleh analogi langsung dengan menggunakan nash Al-Quran dan hadis karena yang berhak untuk itu adalah seorang mujtahid. Bahkan sikap yang lebih ekstrim lagi adalah apa yang telah dikatakan oleh salah satu ulama hanafiah (Al Karkhi): "Setiap ayat atau hadis yang tidak sesuai dengan pendapat imam kita (Abu

\footnotetext{
${ }^{27}$ Jamal al Banna, Nahwa Fiqh Jadid (Dar al Fikr al Islami), jilid. III, h. 217
} 
Hanifa) harus dinasakh atau dita'wil." Kita boleh heran kenapa orang sekaliber Al Karkhi sampai mengatakan seperti itu? Sebabnya tidak lain adalah karena adanya t'asshub mazhab dan pengkultusan terhadap tokohnya.

Kalau kelompok ulama sebelumnya menganggap nash adalah semua teks Al-Quran dan hadis, maka kelompok ulama kedua menganggap bahwa yang dimaksud nash adalah berupa teks ulama klasik. Dalam hal ini, eksplorasi hukum hanya berkutat dalam lingkaran teks ulama klasik tersebut. Fenomena ini tentunya lebih jauh ke belakang dari yang pertama, sebab kelompok ulama yang sebelumnya masih mengakui adanya ijtihad dan boleh langsung menyentuh nash Al-Quran maupun hadis, sedangkan kelompok ulama yang kedua tidak mengakuinya.

Problem pengkaburan makna nash yang sudah sampai pada taraf penyamaan nash AlQuran dan nash ulama sudah terjadi sejak dulu. Menurut M. Arkoun pembedaan antara AlQuran dengan tafsir fuqaha sangat urgen karena antara keduanya memang secara dasar tidak patut disamakan, sebab yang satu dari Tuhan dan lain merupakan pemikiran manusia murni. Menurut Arkoun, perlu diletakkan jarak antara maqâshid Al-Quran dan apa yang disebut oleh Imam Syatibi maqâshid syariah. Melakukan pembedaan diantara keduanya merupakan tugas penting, sebab keduanya akan memotong jalan "ulama" kontemporer yang tidak segan-segan menkafirkan orang hanya untuk menjaga status sosial yang ia miliki dan monopoli kebenaran karena tidak ada kemampuan rasionalitas dan intelektualitas untuk memahami seluk beluk hukum-hukum yang mereka capai melalui nash wahyu. ${ }^{28}$

\section{Kesimpulan}

Menyamakan kedudukan nash kitabkitab fiqh dengan nash-nash syariat merupakan kesalahan. Karena kita perlu melakukan pembaharuan secara terus menerus untuk melakukan kritik terhadap pemikiran yang salah tentang fiqh. Pembaharuan dalam bidang pemikiran fiqh harus dilakukan melalui kajian tentang tajdîd untuk menjawab tantangan perubahan zaman. Tulisan ini hanya sekedar memberikan gambaran singkat bahwa syariat Islam yang mempunyai makna al-Qur'an dan al-Sunnah sebagai syariat Allah yang paripurna untuk dapat menjawab tantangan perubahan zaman. Mekanisme ijtihâd yang ditempatkan pada posisi yang semestinya merupakan kunci untuk menjawab semua itu.

\footnotetext{
${ }^{28}$ M. Arkoun, Min aI Ijtihad ila Naqd al Aqli al Islami (Dar al Saqi), h. 70
} 


\section{DAFTAR PUSTAKA}

Audah, Jaseer. Maqasid As Philoshophy Of Islamic Law. London: The International Institute Of Islamic Thought, 2008.

Audah, Jaseer. Maqasid al- Shari'ah Falsafah Li al-Tashri'i al-Islami. London: The International Institute Of Islamic Thought, 2007.

Arkoun, Muhammad. Min aI Ijtihad ila Naqd al Aqli al Islami. Dar al Saqi, t.t.

Al-Syatibi, Abu Ishaq. al-Muwafaqat fi Ushul al-Fiqh. Bairut: Dar al-Kutub al'Ilmiyah, t.t.

Al-Banna, Jamal. Nahwa Fiqh Jadid. Beirut: Dar al Fikr al Islami, t.t

Al-Zuhayli, Wahbah. Tajdîd Al-Fiqh AlIslamy. Bairut: Dar Al-Fikr, t.t.

Al-Jabiri, Muhammad Abid. Takwin al- 'Aql al'Arabi. Beirut: Al-Markaz al-Tsaqafî al'Arabi, t.t.

Al-Razi, Muhammad Ibn 'Umar. al-Mahsu., ed Taha Jabir al-Alwani. Riyadh: Imam Muhammad University Press, $1400 \mathrm{H}$

El Fadl, Khaled Abou. Speaking in God's Name, Islamic Law, Authority, and
Women, Oxford: Oneworld Publication, 2003, edisi bahasa Indonesia, Atas Nama Tuhan. Jakarta: Serambi, 2004.

Esack, Farid. Membebaskan Yang Tertindas. Bandung: Penerbit Mizan, 2000

http://imadu.multiply.com/journal/item/5.

http://pwkpersis.wordpress.com/2008/05/29/taj did-al-fiqh-why-not/ diakses tanggal 24 Januari 2010

http://www.facebook.com/note.php?note_id =199877905389Membongkar Jabiri, Abid al, al Din wa al Daulah wa Tatbiq al Syariah, http://www.mizanpoenya.co.cc/2010/08/kritik-nalar-fiqhmenuju-fiqh-yang.html

Otoritarianisme dalam Hukum Islam oleh Mohamad Guntur Romli pada 31 Oktober 2009 jam 11:21

Yasid, Abu. Islam Akomadif: Rekonstruksi Pemahaman Islam Sebagai Agama Universal. Yogyakarta: Lkis, 2004

Zayd, Nashr Hamid Abu. Naqd al-Khithâb alDini. Cairo: Madbuli, 1995 